\title{
PENDIDIKAN KESEHATAN MANFAAT PERMEN JAHE UNTUK MENGATASI HYPEREMESIS GRAVIDARUM PADA IBU HAMIL
}

\author{
Febi Ratnasari ${ }^{1}$, Eni Haryati ${ }^{2}$, Gena Devitria ${ }^{3}$, Fitri Amalia Syaputri ${ }^{4 *}$, Aldy \\ Fauzi $^{5}$, Elis Menggawanti ${ }^{6}$ \\ 1,3,4,5,6 STIKes Yatsi Tangerang, Banten \\ ${ }^{2}$ Akper Buntet Pesantren Cirebon, Jawa Barat \\ Email Korespondensi: fitriamaliasy@gmail.com
}

Disubmit: 05 Juli 2021

Diterima: 24 Agustus 2021

Diterbitkan: 02 Februari 2022

DOI: https://doi.org/10.33024/jkpm.v5i2.4622

\begin{abstract}
ABSTRAK
Hyperemesis Gravidarum merupakan keadaan umum menjadi buruk sehingga ibu kekurangan energi dan juga zat gizi. Untuk meningkatkan pengetahuan pada ibu tentang manfaat permen jahe untuk mengatasi Hyperemesis Gravidarum pada ibu hamil. Bahan yang digunakan adalah permen jahe. Metode yang dilaksanakan dengan cara pertemuan virtual zoom meeting dilakukan dengan memberikan google form pre-test, ceramah lalu dilanjutkan dengan tanya jawab antar peserta dan pemateri selama acara berlangsung. Setelah itu diberikan google form post-test untuk mengetahui hasil akhir. Hasil: Target peserta webinar yang sudah direncanakan sebelumnya adalah paling tidak 100 orang peserta yaitu mahasiswa dan masyarakat umum. Dalam pelaksanaanya, kegiatan ini diikuti oleh 100 orang peserta sehingga target peserta tercapai $100 \%$. Dilihat dari pengisian google form post-test peserta yang rata-rata mendapatkan nilai diatas 70, maka dapat disimpulkan bahwa tujuan kegiatan ini tercapai. Diharapkan masyarakat khususnya ibu pada hamil agar dapat mengetahui penanganan yang baik untuk mengkonsumsi permen jahe supaya dapat mengurangi Hyperemesis Gravidarum yang dirasakan.
\end{abstract}

Kata Kunci: Hyperemesis Gravidarum, Ibu Hamil, Permen Jahe

\begin{abstract}
Hyperemesis Gravidarum is a common condition that causes the mother to lack energy and nutrients. To increase knowledge of mothers about the benefits of ginger candy to overcome Hyperemesis Gravidarum in pregnant. The material used is ginger candy. The method which is carried out by means of virtual zoom meetings is done by giving Google pre-test forms, lectures and then followed by questions and answers between participants and presenters during the event. After that, a google post-test form was given to find out the final results. The target for the webinar that has been planned previously is at least 100 participants, namely students and the general public. In its implementation, this activity was attended by 100 participants target of participants was achieved $100 \%$. Judging from filling out the google post-test form, participants who averaged scores above 70, it can be concluded that the purpose of this activity was achieved. It is hoped that the public, especially pregnant, can find
\end{abstract}


out good treatment for consuming ginger candy in order to reduce the perceived Hyperemesis Gravidarum.

Keywords: Ginger Candy, Hyperemesis Gravidarum, Pregnant

\section{PENDAHULUAN}

Kehamilan merupakan sesuatu yang wajar terjadi pada wanita usia produktif, tetapi kurangnya pengetahuan berkaitan dengan reproduksi dapat menimbulkan kecemasan tersendiri (Handayani, 2017). Dalam kehamilan mual muntah adalah gejala yang normal dan sering terjadi pada trimester pertama (Setyawati et al, 2014). Namun, apabila berlebihan dapat mengganggu pekerjaan sehari-hari dan keadaan umum menjadi buruk sehingga ibu kekurangan energi dan juga zat gizi yang disebut Hyperemesis Gravidarum (Rofi'ah et al, 2019).

Hyperemesis Gravidarum terjadi di seluruh dunia dengan angka kejadian beragam mulai dari 0,3\% di Swedia, 0,5\% di California, 0,8\% di Canada, 10,8\% di China, 0,9\% di Norwegia, 2,2\% di Pakistan dan 1,9\% di Turki dan 0,5\%-2\% di Amerika Serikat (Oktavia, 2016). Sedangkan di Indonseia menurut Survey Demografi Kesehatan Indonesia (SDKI) komplikasi kehamilan dengan Hyperemesis Gravidarum terjadi sekitar 3\% (SDKI, 2017).

Tujuan umum ini untuk meningkatkan pengetahuan pada ibu tentang manfaat permen jahe untuk mengatasi Hyperemesis Gravidarum pada ibu hamil.

\section{MASALAH}

Masih rendahnya tingkat pengetahuan tentang manfaat permen jahe untuk mengatasi Hyperemesis Gravidarum pada ibu hamil. Selanjutnya peneliti menentukan atribut yang dibutuhkan oleh ibu untuk dapat melakukan cara pembuatan permen jahe secara mandiri. Penentuan atribut tersebut melalui proses wawancara terhadap beberapa ibu hamil.

\section{METODE}

Metode yang digunakan virtual zoom meeting yang diikuti oleh 100 orang peserta dengan memberikan google form pre-test, ceramah lalu dilanjutkan dengan tanya jawab antar peserta dan pemateri selama acara berlangsung. Setelah itu diberikan google form post-test untuk mengetahui hasil akhir.

\section{HASIL DAN PEMBAHASAN}

Hasil kegiatan webinar berupa penyuluhan ini, secara garis besar mencakup beberapa komponen sebagai berikut :

1. Keberhasilan target jumlah peserta

2. Ketercapaian tujuan webinar

3. Ketercapaian target materi yang telah direncanakan

4. Kemampuan peserta dalam memahami materi

Target peserta webinar yang sudah direncanakan sebelumnya adalah paling tidak 100 orang peserta yaitu mahasiswa dan masyarakat umum. Dalam pelaksanaanya, kegiatan ini diikuti oleh 100 orang peserta. Dengan demikian dapat dikatakan bahwa target peserta tercapai 100\%. Angka tersebut menunjukan bahwa kegiatan webinar dilihat dari jumlah peserta yang mengikuti dapat dikatakan berhasil atau sukses. 
Kegiatan webinar ini dilakukan secara virtual sehingga sinyal berpengaruh besar pada kegiatan, namum pada saat pemateri menyampaikan materi tidak ada kendala. Dilihat dari hasil post test peserta yang rata-rata mendapatkan nilai diatas 70, maka dapat disimpulkan bahwa tujuan kegiatan ini tercapai. Ketercapaian target materi pada kegiatan webinar ini cukup baik, karena materi telah dapat disampaikan secara keseluruhan. Materi yang telah disampaikan adalah :

1. Hypermesis Gravidarum, apa dan mengapa

2. Asuhan keperawatan pada Hypermesis Gravidarum

3. Pembuatan/cara permen jahe sebagai cara awal untuk mengurangi Hypermesis Gravidarum

Kemampuan peserta khususnya masyarakat sebelum diberikan penyuluhan kurang mengenai Hypermesis Gravidarum dan cara penanganannya secara nonfarmakologis, dikarenakan masyarakat yang mengikuti webinar dari berbagai kalangan.. Berdasarkan teori Hypermesis Gravidarum dapat ditangani dengan nonfarmakologis salah satunya yaitu dengan permen jahe (Marlina, 2019). Menurut Maghfiroh, 2016. Terdapat pengaruh permen jahe terhadap penurunan mual muntah pada ibu hamil trimester 1. Menggunakan jahe setara dengan penanganan menggunakan dengan B6, jahe juga mempunyai kelebihan yaitu mempunyai aroma atsiri yang segar dan memberikan kehangatan dalam tubuh. (Oksitosin, Kebidanan, Vol. II, No. 2, Agustus 2016: 111-118). Kami memberikan penyuluhan dengan metode ceramah dan cara membuat permen jahe (Jurnal Bhamada : Jurnal Ilmu Dan Teknologi Kesehatan, Vol. 8, No. 1, April 2019).

Secara keseluruhan kegiatan penyuluhan ini dapat dikatakan berhasil. Keberhasilan ini selain diukur dari keempat komponen diatas, juga dilihat dari hasil post test peserta terhadap pemaparan materi yang sudah dijelaskan dan para peserta dapat mengingat materi yang sudah disampaikan, hal ini mneyimpulkan bahwa setelah penyuluhan terdapat peningkatan pengetahuan mahasiswa dan masyarakat yang benar mengenai materi yang sudah disampaikan dan hal ini sejalan dengan (Oksitosin, Kebidanan, Vol. II, No. 2, Agustus 2016: 111-118). Kami berharap manfaat yang diperoleh peserta adalah dapat memahami apa itu Hypermesis Gravidarum dan juga cara penanganannya dengan non farmakologi.

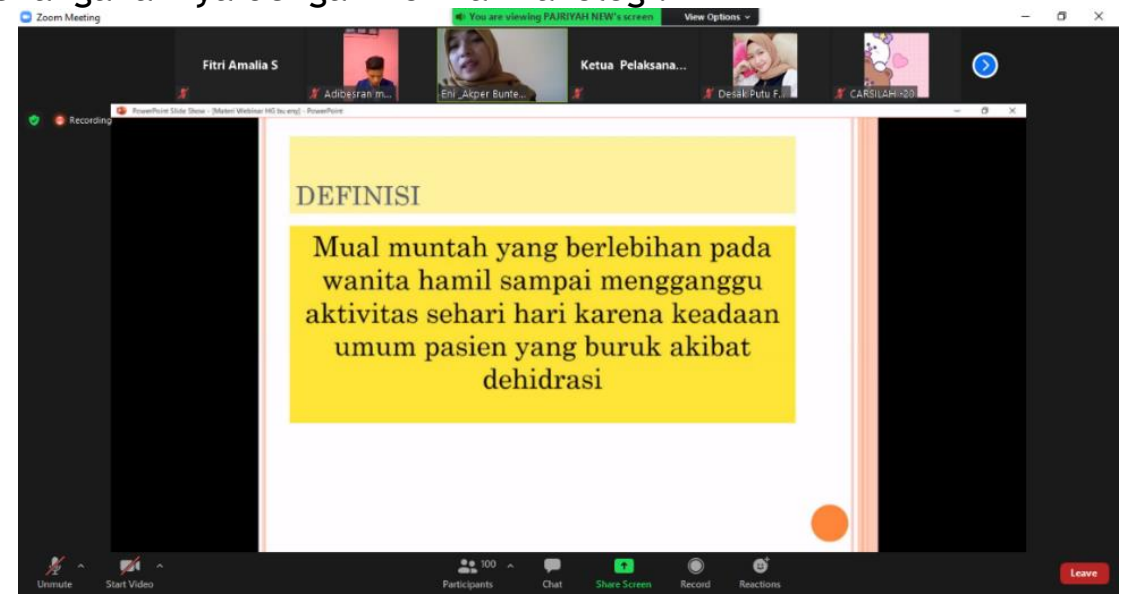




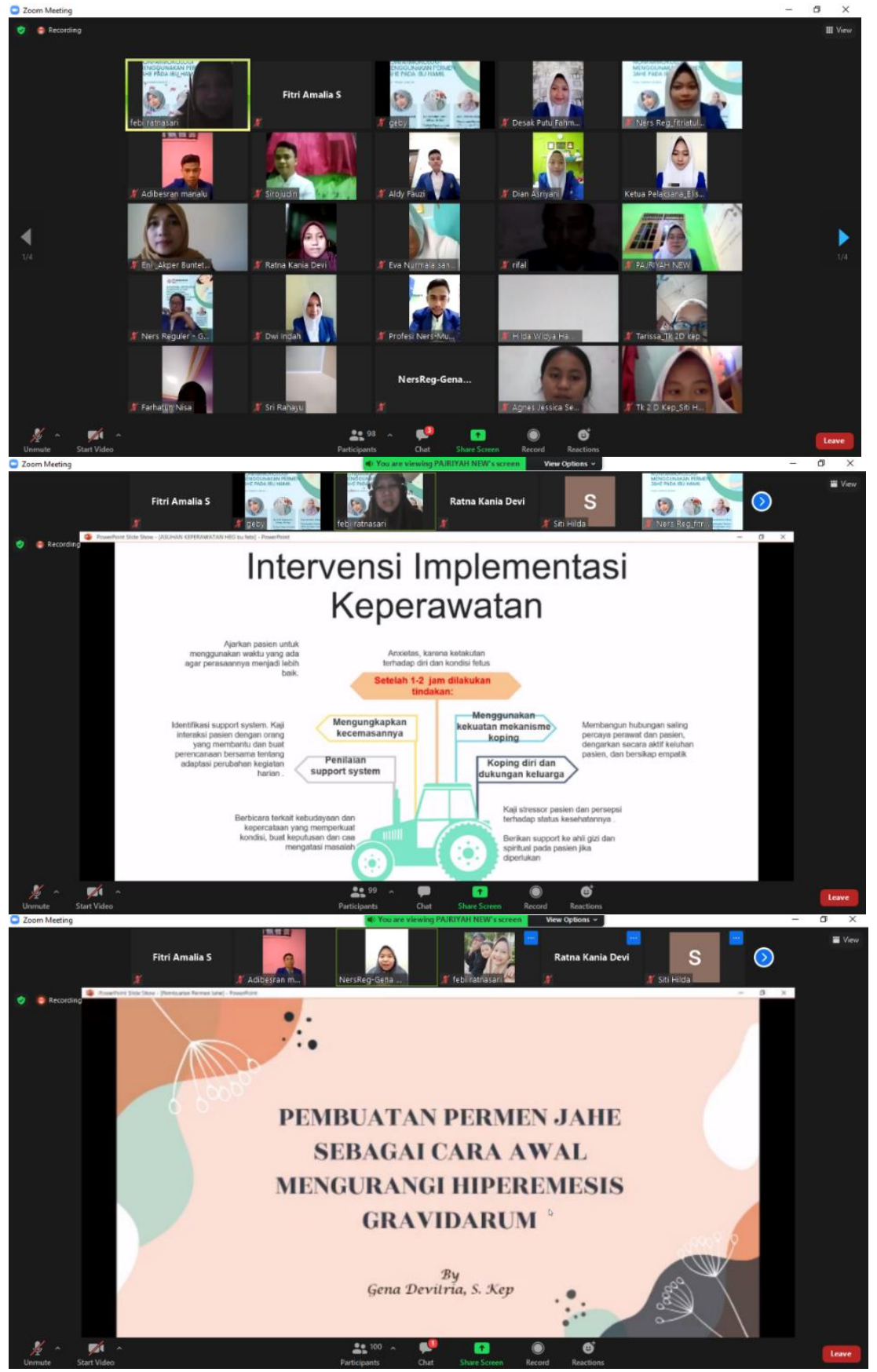

Gambar 1. Poto pelaksanaan kegiatan

\section{KESIMPULAN}

Permen jahe adalah sebuah jenis kembang gula yang berbahan dasar gula dan jahe. Permen jahe merupakan permen yang tergolong kuno. Saat ini banyak permen jahe beredar dipasar dalam negeri maupun luar negeri. Jahe yang merupakan bahan dasar panganan ini memiliki fungsi luar biasa dan mengandung berbagai jenis nutrisi seperti magnesium, tembaga, vitamin $\mathrm{C}$, mangan, kalium dan berbagai jenis bahan antioksi dan alami yang bisa membuat badan menjadi lebih segar. Rempah ini juga berfungsi mengatasi berbagai kondisi mulai dari 
mual dan muntah, batuk, nyeri menstruasi, mencegah morningsickness, mual dan muntah usai operasi.

Hyperemesis Gravidarum adalah mual dan muntah berlebihan yang terjadi pada wanita sehingga menyebabkan terjadinya ketidakseimbangan kadar elektrolit, penurunan berat badan, dehidrasi dan kekurangan nutrisi. Dilihat dari pengisian google form post-test peserta yang rata-rata mendapatkan nilai diatas 70, maka dapat disimpulkan bahwa tujuan kegiatan ini tercapai.

\section{DAFTAR PUSTAKA}

Fadlun. (2014). Asuhan Kebidanan Patologis. Jakarta: Salemba Medika.

Handayani, R. (2017). Faktor-Faktor Yang Berhubungan Dengan Tingkat Kecemasan Menjelang Persalinan Pada Ibu Primigravida Trimester III di Wilayah Kerja Puskesmas Lubuk Buaya Padang Tahun 2012. NERS Jurnal Keperawatan, 11. https://doi.org/10.25077/njk.11.1.60-69.2015

Irna Nisaulkhusna Kadir, Sitti Saleha, N. (2019). Manajemen Asuhan Kebidanan Antenatal Care pada Ny "N" dengan Hiperemesis Gravidarum Tingkat III di Rsud Syekh Yusuf Gowa Tanggal 3 Juni-12 Juli 2019. 1(2), 110-128. Retrieved from http://journal.uinalauddin.ac.id/index.php/jmidwifery/article/view/10832

Kemenkes. (2016). Folmarium Obat Herbal Asli Indonesia. Jakarta. Sekretariat Jendral Kementrian Kesehatan RI.

Khayati, N. (2013). Asuhan Kebidanan Ibu..., Nur Khayati, Kebidanan DIII UMP, 2013. 11-68.

Nurarif, A. H. \& Kusuma, H. (2016). Asuhan Keperawatan Praktis Berdasarkan Penerapan Diagnosa Nanda, NIC, NOC dalam berbagai kasus. Jogjakarta: Medication Jogja.

Oktavia, L. (2016). Kejadian hiperemisis gravidarum ditinjau dari jarak kehamilan dan paritas. 1(2).

Putri, Ayu., D Andiani dan Haniarti. (2016). Efektifitas Pemberian Jahe Hangat Dalam Mengurangi Frekuensi Mual Muntah Pada Ibu Hamil Trimester I. Prosiding Seminar Nasional IKAKESMADA "Peran Tenaga Kesehatan dalam Pelaksanaan SDGs".

Rofi'ah, S., Widatiningsih, S., \& Arfiana. (2019). Studi Fenomenologi Kejadian Hiperemesis Gravidarum Pada Ibu Hamil Trimester I. Jurnal Riset Kesehatan. https://doi.org/10.31983/jrk.v8i1.3844

Runiari, N. (2014). Penerapan Konsep dan Teori Keperawatan. Jakarta: Salemba Medika

SDKI. (2017). Survei Demografi dan Kesehatan Indonesia tahun 2017. Retrieved from http://sdki.bkkbn.go.id/files/buku/2017IDHS.pdf

Setyawati, N., Wahyuningsih, M. S. H., \& Nurdiati, D. S. (2014). Pemberian jahe instan terhadap kejadian mual muntah dan asupan energi pada ibu hamil trimester pertama. Jurnal Gizi Klinik Indonesia, 10(4), 191. https: / / doi.org/10.22146/ijcn.18871

Wiknjosastro, H. (2014). Ilmu Kebidanan. Jakarta: Yayasan Bina. Pustaka Sarwono Prawirohardjo. 